\title{
P7 peptides targeting bFGF sensitize colorectal cancer cells to CPT-11
}

\author{
WU LUO $^{1 *}$, YONGLIN YU $^{1 *}$, RUIXUE WANG $^{1}$, DAN HE $^{1}$, CONG WANG $^{1,2}$, XIANGFENG ZENG $^{1}$, \\ XILEI CHEN $^{1}$, XIANGPENG TAN $^{1}$, TAO HUANG $^{1}$ and XIAOPING WU ${ }^{1,2}$ \\ ${ }^{1}$ Institute of Tissue Transplantation and Immunology, Jinan University, Guangzhou, Guangdong; \\ ${ }^{2}$ School of Pharmaceutical Science, Wenzhou Medical College, Wenzhou, Zhejiang, P.R. China
}

Received July 19, 2013; Accepted October 4, 2013

DOI: $10.3892 /$ ijmm.2013.1547

\begin{abstract}
The low survival rate of patients with colorectal cancer (CRC) is mainly due to the drug resistance of tumor cells to chemotherapeutic agents. It has been reported that basic fibroblast growth factor (bFGF) is an essential factor involved in the epigenetic mechanisms of drug resistance, which provides a novel potential target for improving the sensitivity of tumor cells to chemotherapeutic agents. In this study, we first demonstrate that a novel bFGF antagonist, peptide P7, previously isolated by phage display technology, reversed bFGF-induced resistance to irinotecan hydrochloride (CPT-11), and counteracted the anti-apoptotic effects of bFGF on CPT-11-treated HT-29 cells. Further experiments indicated that the inhibition of Akt activation, the suppression of bFGF internalization, the increase in the Bax to $\mathrm{Bcl}-2$ ratio and the downregulation of cytokeratin 8 (CK8) by P7 may contribute to the counteracting of the anti-apoptotic effects of bFGF, and further reversal of bFGF-induced resistance to CPT-11. Our results suggest that peptide $\mathrm{P} 7$ may have therapeutic potential in CRC as a sensitizer to chemotherapeutic agents by targeting bFGF.
\end{abstract}

\section{Introduction}

Colorectal cancer (CRC) is the fourth most common malignant tumor worldwide, leading to approximately 200,000 deaths per year in Europe and the US (1). Although improved surgical techniques combined with multi-disciplinary approaches have been applied in therapy, the 5-year survival rate for patients with CRC remains poor, mainly due to tumor cells acquiring

Correspondence to: Dr Xiaoping Wu, Institute of Tissue Transplantation and Immunology, Jinan University, 601 West Huangpu Avenue, Tianhe, Guangzhou, Guangdong 510632, P.R. China

E-mail: twxp@jnu.edu.cn

*Contributed equally

Key words: basic fibroblast growth factor, drug resistance, apoptosis, colorectal cancer multidrug resistance properties. The overexpression of drug efflux proteins (2-4) is considered a common mechanism of multidrug resistance, as shown in preclinical studies. However, no significant improvement in the chemotherapeutic effectiveness has been observed in clinical practice by the inhibition of drug efflux proteins $(5,6)$, suggesting the existence of other chemoresistance mechanisms.

Irinotecan hydrochloride (CPT-11) is a water-soluble derivative of camptothecin (7), presenting a wide spectrum of antitumor activity by preventing DNA religation, resulting in DNA double-strand breaks and eventually leading to apoptosis (8). The cytotoxic activity of CPT-11 has been reported in several malignant tumors, including breast, lung, ovarian, and colon cancer (9-16). CPT-11 serving as a DNA topoisomerase I inhibitor, combined with 5-fluorouracil (5-FU) and leucovorin has been accepted as a first-line treatment for patients with advanced CRC. However, this combination only offers a 2-month median survival advantage over previous chemotherapeutic agents (8). Any treatment conferring a modest survival benefit for CRC will have significant meaning. Understanding the mechanisms of drug resistance will greatly contribute to the development of more effective treatments for improving survival in patients with CRC.

Basic fibroblast growth factor (bFGF) is a pleiotropic factor involved in the processes of cell proliferation, differentiation and anti-apoptosis in a wide variety of cells derived from the mesoderm and neuroectoderm. It has been well documented that bFGF plays an essential role in tumor growth and progression by stimulating the proliferation of tumor cells and promoting angiogenesis (17-19). During chemotherapy in CRC, CPT-11 enhances the levels of intratumoral bFGF, and upregulates bFGF levels in recurrent tumors following chemotherapy, suggesting that elevated levels of extracellular bFGF may mediate an epigenetic mechanism of multidrug resistance. bFGF serving as a key factor involved in an epigenetic mechanism by which cancer cells become resistant to chemotherapeutic agents may provide a novel potential target for designing strategies to sensitize tumor cells to chemotherapeutic drugs.

In our previous studies, using phage display technology, we obtained a novel bFGF antagonist peptide (named P7) with strong inhibitory activity against bFGF-induced cell proliferation and angiogenesis $(20,21)$. Our results suggested that 
P7 peptides may bind to bFGF and block the biological activities of bFGF. In this study, we aimed to investigate the effects and mechanisms of action of our previously isolated $\mathrm{P} 7$ peptide on the bFGF-induced resistance of CRC cells to CPT-11.

\section{Materials and methods}

Materials. The CRC cell line, HT-29, was kept in our laboratory. Recombinant human bFGF was obtained from PeproTech, Inc. (Rocky Hill, NJ, USA). P7 peptides (PLLQATLGGGS) with a purity of $>98 \%$ were synthesized at SBS Genetech Co., Ltd. (Beijing, China). Dynabeads ${ }^{\circledR}$ M-280 Streptavidin, Dynamag-2 magnet, RMPI-1640 medium and fetal bovine serum (FBS) were obtained from Invitrogen (Carlsbad, CA, USA). Antiphospho-Akt, anti-Akt, anti-Bcl-2, anti-Bcl-xL, anti-Bax and anti-GAPDH antibodies were purchased from Cell Signaling Technology (Danvers, MA, USA). Polyvinylidene difluoride (PVDF) membranes were purchased from Millipore (Billerica, MA, USA). The enhanced chemiluminescence (ECL) detection kit was the product of Pierce (Rockford, IL, USA). The Alexa Fluor ${ }^{\circledR} 488$ Annexin V/PI kit was from Invitrogen. The SYBR-Green qPCR Master Mix was the product of Tiangen Biotech (Beijing, China). The materials for 2-dimensional gel electrophoresis, including immobilized $\mathrm{pH}$ gradient (IPG) strips (pH 3-10 non-linear), CHAPS, Bio-Lyte 3-10 Ampholyte $40 \%$ solution, acrylamide, methylene-bisacrylamide, sodium dodecyl sulfate (SDS), tetramethylethylenediamine (TEMED) and iodoracetamide were the products of Bio-Rad (Hercules, CA, USA). Glycerol and ammonium persulfate were purchased from Sigma (St. Louis, MO, USA). Dithiothreitol (DTT) and urea were obtained from Promega (Madison, WI, USA).

Cell viability assay. The cells were seeded into 96-well culture plates at a density of $5 \times 10^{3}$ cells/well and cultured overnight. After being starved in RMPI-1640 medium with $0.4 \%$ FBS for $24 \mathrm{~h}$, the cells were treated with serially diluted CPT-11 $(15,30,60,120,180 \mu \mathrm{M})$ for $48 \mathrm{~h}$. The $\mathrm{IC}_{50}$ of CPT-11 was determined by MTT colorimetric assay.

After determining the $\mathrm{IC}_{50}$ of CPT-11 as $60 \mu \mathrm{M}$, the cells were further treated as follows: with $60 \mu \mathrm{M}$ CPT-11 alone, $60 \mu \mathrm{M}$ CPT-11 plus $20 \mathrm{ng} / \mathrm{ml}$ bFGF, or $60 \mu \mathrm{M}$ CPT-11 plus $20 \mathrm{ng} / \mathrm{ml} \mathrm{bFGF}$ combined with $4 \mu \mathrm{M}$ P7. The viability of the cells was determined by MTT colorimetric assay following incubation for $48 \mathrm{~h}$.

Apoptosis assay. The cells were seeded in a 6-well plate at a density of $4 \times 10^{5}$ cells/well, starved in RMPI-1640 medium with $0.4 \%$ FBS overnight, and then treated with $60 \mu \mathrm{M} \mathrm{CPT}-11$ alone, $60 \mu \mathrm{M}$ CPT-11 plus $20 \mathrm{ng} / \mathrm{ml} \mathrm{bFGF}$, or $60 \mu \mathrm{M}$ CPT-11 plus $20 \mathrm{ng} / \mathrm{ml} \mathrm{bFGF}$ combined with $4 \mu \mathrm{M}$ P7 for $48 \mathrm{~h}$. After being washed with cold PBS twice, the cells were resuspended in 1X Annexin-binding buffer, incubated with Alexa Fluor 488 Annexin V and PI for $15 \mathrm{~min}$ in the dark at room temperature, and subjected to flow cytometric analysis. FCS Express version 3 software was applied to analyze the apoptotic ratio of the cells.

Akt activation assay. The cells were seeded in a 12-well plate at a density of $5 \times 10^{5}$ cells/well and cultured overnight. After being starved for $24 \mathrm{~h}$, the cells were pre-treated with $20 \mathrm{ng} / \mathrm{ml} \mathrm{bFGF}$, or $20 \mathrm{ng} / \mathrm{ml} \mathrm{bFGF}$ combined with $4 \mu \mathrm{M} \mathrm{P} 7$ for $4 \mathrm{~h}$ prior to treatment with $60 \mu \mathrm{M}$ CPT-11. After being washed twice with cold $\mathrm{PBS}$, the cells were harvested and centrifuged at $12,000 \mathrm{x} \mathrm{g}$ for $10 \mathrm{~min}$ at $4^{\circ} \mathrm{C}$ to remove the insoluble components. The resultant protein samples were separated by $10 \%$ SDS-PAGE gel and were then transferred onto a PVDF membrane. In order to block non-specific binding, the membrane was incubated with 5\% non-fat milk in TBST (25 mM Tris, $\mathrm{pH} 7.4,150 \mathrm{mM}$ $\mathrm{NaCl}$ and $0.1 \%$ Tween-20) buffer for $1 \mathrm{~h}$. After being washed with TBST 3 times, the membrane was incubated with primary antibody [an anti-phospho-Akt rabbit monoclonal antibody (mAb) or an anti-Akt rabbit $\mathrm{mAb}$ ] overnight followed by probing with goat anti-rabbit IgG, HRP-linked antibody for $1 \mathrm{~h}$ at room temperature. The ECL detection kit was used to detect the proteins on the blots. The relative ratio was determined by Quantity One software.

bFGF internalization assay. The biotinylation of bFGF was performed on cysteine residues according to the manufacturer's instructions (Vector Laboratories, Inc., Burlingame, CA, USA). The modification of bFGF at cysteine residues has no effect on the biological activity of the growth factor (22). After being starved for $24 \mathrm{~h}$, the HT-29 cells were pre-treated with $4 \mu \mathrm{M}$ peptides for $5 \mathrm{~min}$ prior to stimulation with $20 \mathrm{ng} / \mathrm{ml}$ biotinylated bFGF (biot-bFGF) for $4 \mathrm{~h}$. The cells were harvested by centrifugation at $250 \mathrm{x} \mathrm{g}$ for $5 \mathrm{~min}$ at $4^{\circ} \mathrm{C}$, and washed twice in cold PBS. The Nuclear and Cytoplasmic Protein Extraction kit was used to extract the nuclear and the cytoplasmic proteins according to the manufacturer's instructions (KeyGen Biotech. Co. Ltd., Nanjing, China). The protein concentrations were determined using the Bradford method, as previously described (23). An equal amount of protein sample was incubated in the presence of streptavidin beads for $30 \mathrm{~min}$ at room temperature with gentle rotation. After extensive washing with PBS containing $0.1 \%$ BSA 5 times, the bound proteins were directly resuspended in $0.1 \%$ SDS by boiling the beads for $5 \mathrm{~min}$ and they were subsequently analyzed by western blot analysis using anti-bFGF antibody.

Analysis of the expression of apoptosis-related proteins. The cells were seeded in a 12 -well plate at a density of $5 \times 10^{5}$ cells/ well and cultured overnight. After being starved for $24 \mathrm{~h}$, the cells were pre-treated with $20 \mathrm{ng} / \mathrm{ml} \mathrm{bFGF,} \mathrm{or} 20 \mathrm{ng} / \mathrm{ml}$ bFGF combined with $4 \mu \mathrm{M}$ P7 for $4 \mathrm{~h}$ prior to treatment with $60 \mu \mathrm{M}$ CPT-11 for $48 \mathrm{~h}$. The cells were harvested and lysed in 1X SDS-PAGE loading buffer. The resultant protein samples were separated by $10 \%$ SDS-PAGE gel and were then transferred onto a PVDF membrane, which was incubated in 5\% non-fat milk in TBST buffer for $1 \mathrm{~h}$, and subsequently with polyclonal antibodies against Bcl-2, Bax, Bcl-xL and GAPDH overnight, and then with HRP-conjugated secondary antibody for $1 \mathrm{~h}$. The ECL detection kit was used to visualize the blots. The results were analyzed using Quantity One software to determine the relative ratio.

2-Dimensional gel electrophoresis (2-DE) and mass spectrometric analysis. The HT-29 cells ( $1 \times 10^{6}$ cells) were grown in cell culture flasks $\left(75 \mathrm{~cm}^{2}\right)$ overnight. After being starved for $24 \mathrm{~h}$, the cells were treated with $60 \mu \mathrm{M} \mathrm{CPT}-11$ alone, $60 \mu \mathrm{M}$ CPT-11 plus $20 \mathrm{ng} / \mathrm{ml} \mathrm{bFGF}$, or $60 \mu \mathrm{M}$ CPT-11 plus $20 \mathrm{ng} / \mathrm{ml}$ 
bFGF combined with $4 \mu \mathrm{M}$ P7 for $48 \mathrm{~h}$. The samples for 2-DE were prepared as follows: $1 \mathrm{mg}$ of protein sample was resuspended in rehydration buffer ( $7 \mathrm{M}$ urea, $2 \mathrm{M}$ thiourea, $4 \%$ CHAPS, 65 mM DTT, 0.2\% pH 3-10 ampholyte, and 0.001\% bromophenol blue) to a total volume of $350 \mu 1$. The resuspended proteins were loaded on a $17-\mathrm{cm}$ immobilized $\mathrm{pH}$ gradient strip and separated first according to the isoelectric point of the proteins. After reduction for $15 \mathrm{~min}$ in equilibration buffer $(6 \mathrm{M}$ urea, $30 \%$ glycerol, $2 \%$ SDS, $50 \mathrm{mM}$ Tris-HCL, pH 8.8 and $2 \%$ DTT) for 15 min and alkylation for an additional $15 \mathrm{~min}$ in the same solution (except that 2\% DTT was substituted with $2.5 \%$ iodoacetamide), the proteins were then separated in $12 \%$ SDS-PAGE gels, followed by staining with Coomassie brilliant blue G-250.

After being analyzed using PDQuest 8.0 software, the protein spots were excised and subjected to in-gel trypsin digestion as previously described (21). The digested samples were dried and analyzed by tandem time-of-flight (TOF) mass spectrometry (ABI 4800 TOF/TOF). Mascot protein identification software was used for peptide detection in the IPI human database.

Real-time PCR (qPCR). Total RNA was isolated from the HT-29 cells using TRIzol reagent according to the manufacturer's instructions (Invitrogen). First-strand cDNA was synthesized from the isolated total RNA using random primers. Relative qPCR was performed with SYBR-Green PCR Master Mix using a MiniOpticon real-time PCR detector. The sequences of the primers used for PCR were as follows: cytokeratin 8 (CK8) forward, 5'-ATCAGCTCCTCGAGCTTCTC-3' and reverse, 5'-TCCAGGAACCGTACCTTGTC-3'; and GAPDH forward, 5'-GAAGGTGAAGGTCGGAGTC-3' and reverse, 5'-AAGATGGTGATGGGATTTC-3'.

Statistical analysis. Data are presented as the means \pm standard deviations (SD) from at least 3 independent experiments and statistical analysis was performed using GradPad Prism software version 5.0. A value of $\mathrm{P}<0.05$ was considered to indicate a statistically significant difference.

\section{Results}

$P 7$ peptides reverse $b F G F$-induced resistance to $C P T-11$. The effects of $\mathrm{P} 7$ peptides on bFGF-induced CPT-11 resistance were evaluated by MTT assay. The results are presented in Fig. 1. CPT-11 inhibited cell growth in a dose-dependent manner, with an $\mathrm{IC}_{50}$ of $60 \mu \mathrm{M}$. At the fixed CPT-11 concentration $\left(\mathrm{IC}_{50}\right)$, bFGF induced resistance to CPT-11, as indicated by the increase in the the survival rate of the HT-29 cells treated with CPT-11 plus bFGF. In the presence of bFGF, the addition of P7 peptides reversed the bFGF-induced resistance to CPT-11.

$P 7$ attenuates the anti-apoptotic effects of bFGF on CPT-11treated cells. It has been known that the failure to activate the apoptotic programme is an essential mode of drug resistance in tumor cells. bFGF has anti-apoptotic potential, and is involved in the induction of the resistance of tumor cells to chemotherapeutic drugs. Therefore, in order to investigate whether the P7 peptide reversed bFGF-induced resistance to CPT-11 by attenuating the anti-apoptotic effects of bFGF, dual staining with Alexa Fluor 488 Annexin V and PI followed by flow
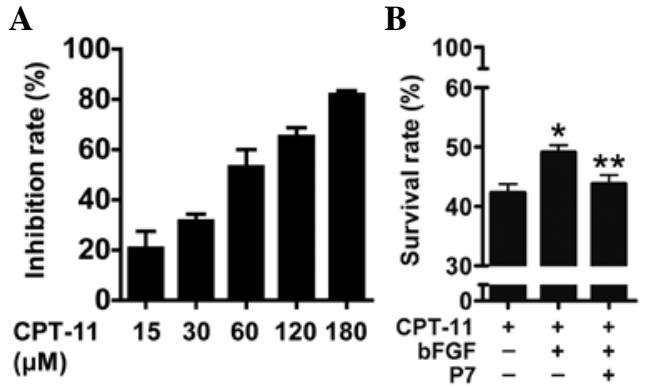

Figure 1. P7 peptides counteract resistance of HT-29 cells to CPT-11 induced by basic fibroblast growth factor (bFGF). (A) Cells were treated with CPT-11 at increasing concentrations (from 15 to $180 \mu \mathrm{M}$ ) for $48 \mathrm{~h}$. (B) Following pre-treatment with bFGF (20 ng/ml) alone, or bFGF (20 ng/ml) plus P7 peptides $(4 \mu \mathrm{M})$ for $4 \mathrm{~h}$, the starved cells were treated with CPT-11 $(60 \mu \mathrm{M})$ for $48 \mathrm{~h}$. Cell viability was measured by MTT assay. Data are presented as the means $\pm \mathrm{SD}$ of 3 independent experiments performed in triplicate. ${ }^{*} \mathrm{P}<0.01 \mathrm{vs}$ CPT-11 group; ${ }^{* *} \mathrm{P}<0.01$ vs. CPT-11 plus bFGF group.

A

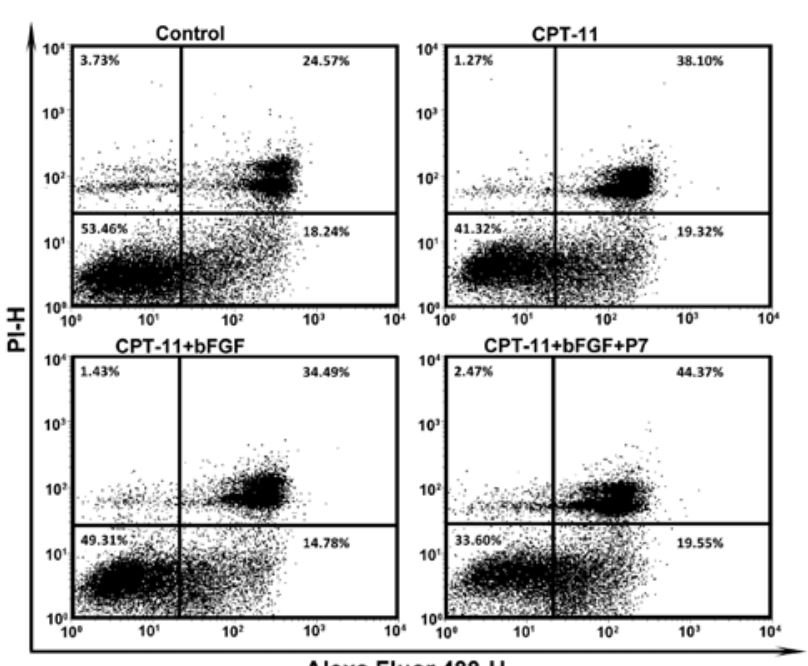

Alexa Fluor 488- $\mathrm{H}$

$\mathbf{B}$

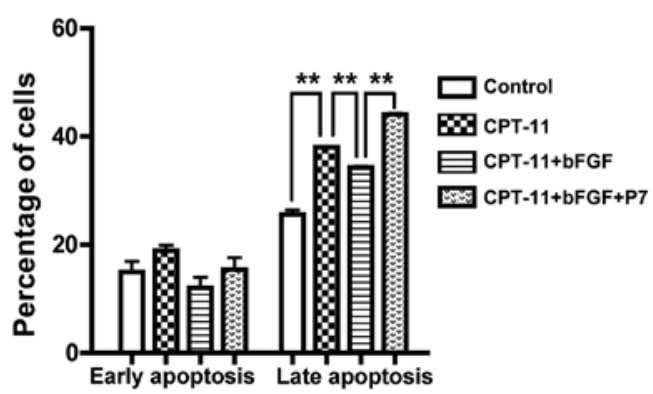

Figure 2. Effects of $\mathrm{P} 7$ peptides on the inhibition of CPT-11-induced apoptosis by basic fibroblast growth factor (bFGF) in HT-29 cells. (A) Following pretreatment with bFGF $(20 \mathrm{ng} / \mathrm{ml})$ alone, or bFGF $(20 \mathrm{ng} / \mathrm{ml})$ plus $\mathrm{P} 7$ peptides $(4 \mu \mathrm{M})$ for $4 \mathrm{~h}$, the starved cells were treated with CPT-11 $(60 \mu \mathrm{M})$ for $48 \mathrm{~h}$. Cells were stained with Alexa Fluor 488 Annexin V and PI prior to analysis by flow cytometry. The lower right quadrant indicates early-stage apoptosis and the upper right quadrant indicates late-stage apoptosis. (B) Comparison of percentages of apoptotic cells. Results are expressed as a mean percentage of cells \pm SD of 3 independent experiments. ${ }^{* *} \mathrm{P}<0.001$.

cytometric analysis was carried out to determine the effects of peptide P7 on apoptosis. As illustrated in Fig. 2, CPT-11 markedly enhanced the apoptotic rate, with the late-stage apoptotic rate increasing from $25.64 \pm 1.33 \%$ to $38.01 \pm 0.12 \%$. Treatment with bFGF decreased the late-stage apoptotic rate 
$\mathbf{A}$

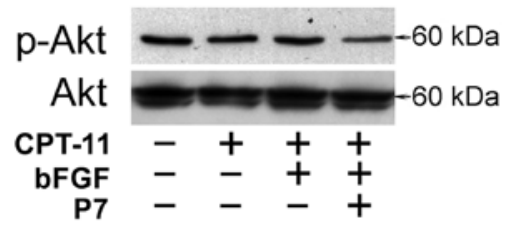

B

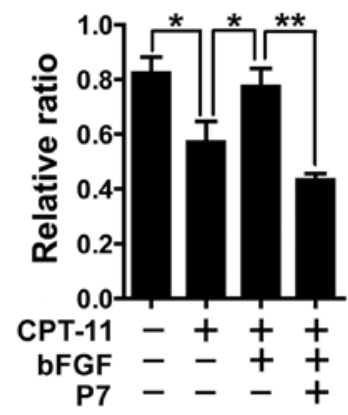

Figure 3. Effects of P7 peptides on the PI3K/Akt signaling pathway in HT-29 cells. (A) Starved cells were pre-treated with basic fibroblast growth factor (bFGF) $(20 \mathrm{ng} / \mathrm{ml})$ alone, or bFGF $(20 \mathrm{ng} / \mathrm{ml})$ plus P7 $(4 \mu \mathrm{M})$ for $4 \mathrm{~h}$ prior to stimulation with CPT-11 $(60 \mu \mathrm{M})$. The phosphorylated and total levels of Akt were determined by western blot analysis. (B) Density ratios of phosphorylated proteins to total proteins are presented as the means \pm SD of 3 independent experiments. ${ }^{*} \mathrm{P}<0.01 ;{ }^{* *} \mathrm{P}<0.001$.

to $34.30 \pm 0.27 \%$; this was then increased to $44.09 \pm 0.29 \%$ by the addition of $\mathrm{P} 7$ peptides, suggesting that $\mathrm{P} 7$ peptides may reverse bFGF-induced CPT-11 resistance by counteracting the anti-apoptotic effects of bFGF on CPT-11-treated cells.

P7 blocks bFGF-induced Akt activation. Since the PI3K/Akt signaling pathway decisively contributes to drug resistance by mediating anti-apoptotic signals, we further examined the effects of P7 peptides on the activation of the PI3K/Akt signaling pathway by western blot analysis. As shown in Fig. 3 , CPT-11 decreased the activation of Akt; however, the addition of bFGF enhanced the phosphorylation of Akt which was downregulated by CPT-11, whereas P7 peptides attenuated the activation of Akt induced by bFGF, revealing that the PI3K/ Akt signaling pathway is involved in mediating the reversal effects of $\mathrm{P} 7$ peptides on bFGF-induced apoptosis and resistance to CPT-11.

$P 7$ inhibits the internalization of $b F G F$. The binding of bFGF with its receptors unleashes its full biological activity, including its anti-apoptotic properties, by activating signal transduction pathways and enabling its internalization into cells (24). Therefore, the effects of P7 peptides on bFGF internalization were further analyzed by anti-bFGF antibody probing exogenous biot-bFGF in the cytoplasmic and nuclear fractions. The intense signals of biot-bFGF were detected in both the cytoplasmic and nuclear proteins extracted from the biot-bFGF treated cells (Fig. 4, lanes 3 and 4), whereas pretreatment of the cells with $\mathrm{P} 7$ peptides $(4 \mu \mathrm{M})$ for 5 min prior to stimulation with biot-bFGF weakened the signals detected in the cytoplasms and nuclei of the cells (Fig. 4, lanes 5 and 6), indicating that $\mathrm{P} 7$ peptides significantly inhibited bFGF internalization, which may partly contribute to the counteracting effects of $\mathrm{P} 7$ peptides, preventing the blockade of apoptosis by

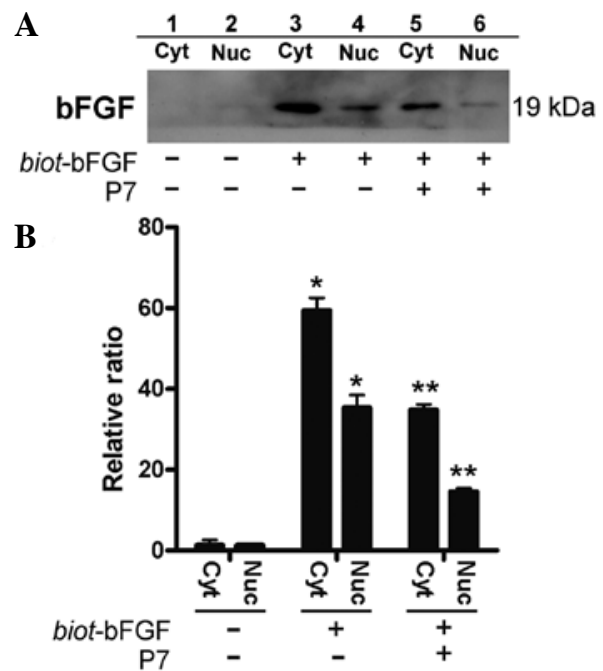

Figure 4. P7 peptides suppress the internalization of basic fibroblast growth factor (bFGF). (A) Starved HT-29 cells were treated with $20 \mathrm{ng} / \mathrm{ml}$ biot-bFGF for $4 \mathrm{~h}$ (lanes 3 and 4 ), or with P7 $(4 \mu \mathrm{M})$ for $5 \mathrm{~min}$ before stimulated by biot-bFGF (lanes 5 and 6). Control cells were untreated with biotinylated (biot)-bFGF or P7 peptides (lanes 1 and 2). Nuclear and cytoplasm extracts were incubated in the presence of streptavidin beads. Proteins bound on streptavidin beads were analyzed by western blot analysis using anti-bFGF antibody. (B) Density ratios of biot-bFGF in nucleus or cytoplasm in bFGF group or bFGF plus $\mathrm{P} 7$ group with the control group are presented as the means $\pm \mathrm{SD}$ of 3 independent experiments. ${ }^{*} \mathrm{P}<0.001$ vs. control group; ${ }^{* *} \mathrm{P}<0.001$ vs. bFGF group.

bFGF in the cells treated with CPT-11, and further reducing bFGF-induced resistance to CPT-11.

$P 7$ counteracts the regulatory effects of bFGF on the expression of apoptosis-related proteins in CPT-11-treated cells. Given that P7 peptides attenuated the anti-apoptotic effects of bFGF in CPT-11-treated cells, and Bcl-2 family proteins play essential roles in modulating the process of apoptosis, western blot analysis was carried out to elucidate the involvement of Bcl-2 family proteins in the effects of $\mathrm{P} 7$ peptides on the apoptosis of HT-29 cells. As shown in Fig. 5, when the HT-29 cells were exposed to $60 \mu \mathrm{M}$ CPT-11, the ratio of Bax to Bcl-2 increased. Pre-treatment with bFGF for $4 \mathrm{~h}$ prior to the administration of CPT-11 downregulated the ratio of Bax to Bcl-2, which was rescued by the addition of P7 peptides. Compared with the control, no significant change in Bcl-xL expression was observed in all the groups. These results suggest that the downregulation of the anti-apoptotic protein, Bcl-2, and the upregulation of the pro-apoptotic protein, Bax, may correlate with the attenuation of the anti-apoptotic effects of bFGF by P7 peptides in CPT-11-treated cells.

Identification of proteins associated with the effects of $P 7$ peptides on bFGF-induced resistance to CPT-11. A proteomic approach based on 2-DE coupled with mass spectrometry was applied to identify proteins participating in the effects of P7 peptides on bFGF-induced resistance to CPT-11 in HT-29 cells. The protein profiles presented in Fig. 6 were first compared between CPT-11-treated and bFGF-stimulated cells to select the specific proteins involved in the bFGF regulation of resistance to CPT-11, and then compared the intensities 
$\mathbf{A}$

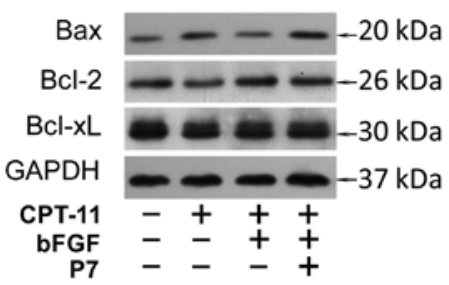

B

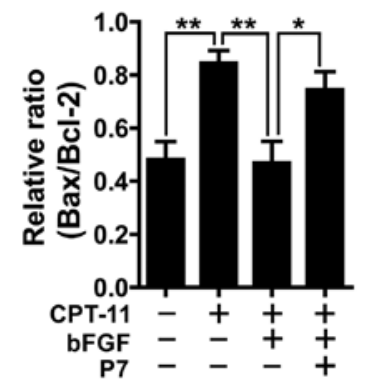

Figure 5. P7 peptides counteract the regulatory effects of basic fibroblast growth factor (bFGF) on the expression of apoptosis-related proteins in HT-29 cells. (A) Following pre-treatment with bFGF (20 ng/ml) alone, or bFGF $(20 \mathrm{ng} / \mathrm{ml})$ plus P7 $(4 \mu \mathrm{M})$ for $4 \mathrm{~h}$, the starved cells were treated with CPT-11 $(60 \mu \mathrm{M})$ for $48 \mathrm{~h}$. Western blot analysis was performed using total cell lysates and antibodies against Bax, Bcl-2 and Bcl-xL. GAPDH was used as a loading control. (B) Density ratios of Bax to Bcl-2 are presented as the means $\pm \mathrm{SD}$ of 3 independent experiments. ${ }^{*} \mathrm{P}<0.01 ;{ }^{* * *} \mathrm{P}<0.001$.

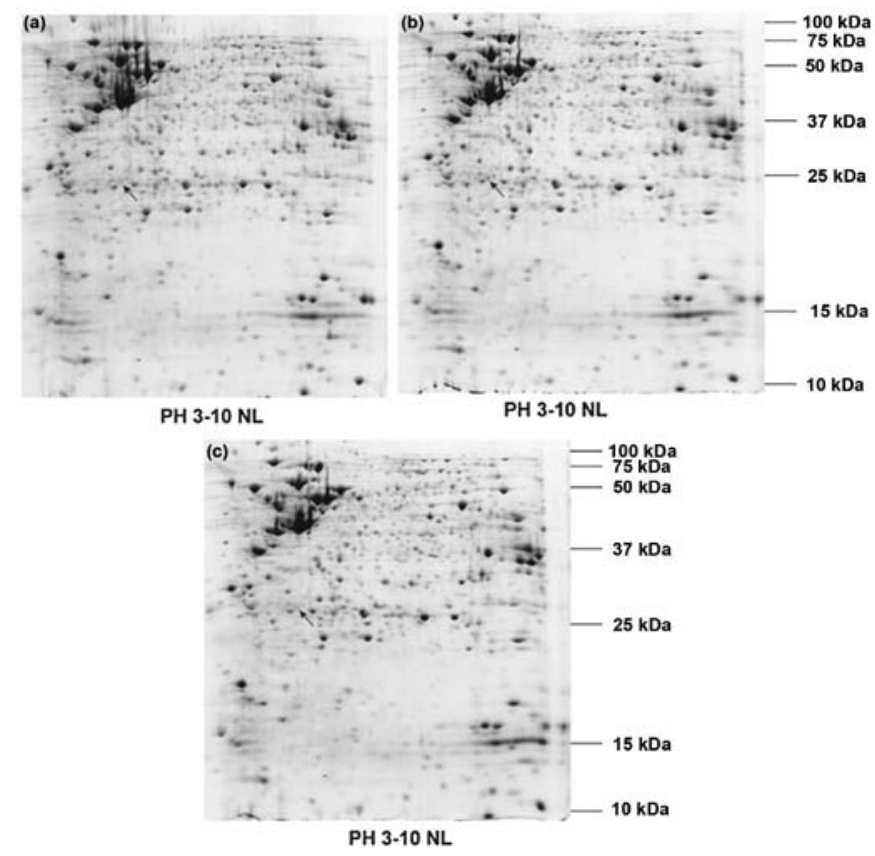

Figure 6. Comparison of the proteomic profiles among the cells treated with (a) $60 \mu \mathrm{M}$ CPT-11, (b) $60 \mu \mathrm{M}$ CPT-11 plus $20 \mathrm{ng} / \mathrm{ml}$ basic fibroblast growth factor (bFGF), and (c) $60 \mu \mathrm{M}$ CPT-11 plus $20 \mathrm{ng} / \mathrm{ml} \mathrm{bFGF}$ combined with $4 \mu \mathrm{M}$ P7. The proteins were separated by $2 \mathrm{D}$ electrophoresis followed by staining with Coommasie brilliant blue G250.

of the selected protein spots between bFGF-stimulated and P7 peptide-treated groups to determine the proteins associated with resistance to CPT-11 which were affected by $\mathrm{P} 7$ peptides targeting bFGF (Fig. 7). The selected differentially expressed protein spots were excised from the gels and then subjected to trypsin digestion; they were then analyzed by matrix-
A
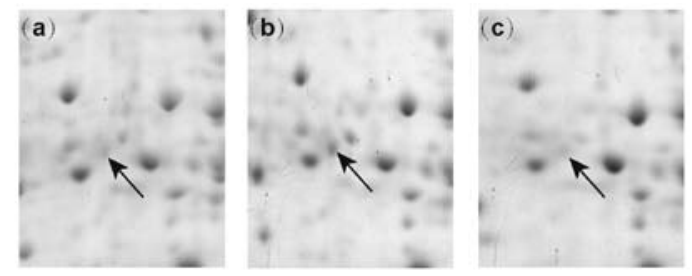

B

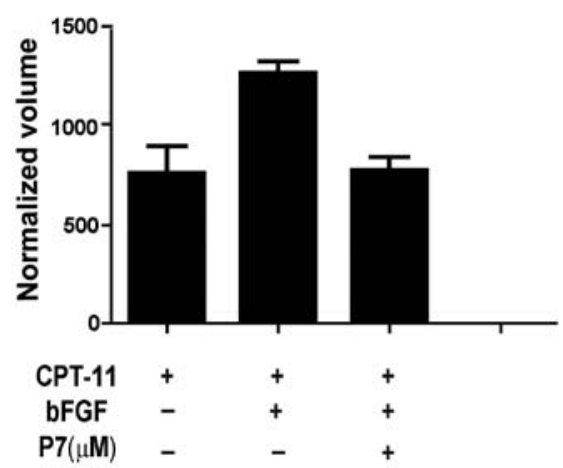

Figure 7. (A) Enlarged maps of the differentially expressed protein spots among the cells treated with (a) CPT-11, (b) CPT-11 plus basic fibroblast growth factor (bFGF) and (c) CPT-11 plus bFGF combined with P7. Arrows indicate the differentially expressed protein spots identified by proteomic analysis. (B) Comparison of the intensity level of the differentially expressed protein spots assigned by PDQuest 8.0 software.

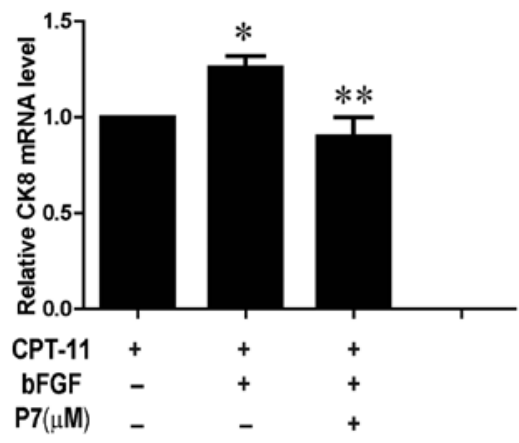

Figure 8. Validation of the expression levels of cytokeratin 8 (CK8). Starved cells were treated with $60 \mu \mathrm{M}$ CPT- 11 alone, $60 \mu \mathrm{M}$ CPT- 11 plus $20 \mathrm{ng} / \mathrm{ml}$ basic fibroblast growth factor (bFGF), or $60 \mu \mathrm{M}$ CPT-11 plus $20 \mathrm{ng} / \mathrm{ml} \mathrm{bFGF}$ combined with $4 \mu \mathrm{M} \mathrm{P7}$ for $48 \mathrm{~h}$. Total RNA was extracted and subjected to analysis of the expression levels of CK 8 by real-time RT-PCR. Results are presented as the means \pm SD of 3 independent experiments. ${ }^{*} \mathrm{P}<0.01$ vs. CPT-11 group; ${ }^{* *} \mathrm{P}<0.01$ vs. CPT-11 plus bFGF group.

assisted laser desorption/ionization (MALDI)-TOF-TOF mass spectrometry. As shown in Table I, the selected proteins were confidently identified by searching the data collected from MALDI-TOF-TOF against the IPI human database with the Mascot online search tool. The expression of the identified protein, CK8, which was increased by bFGF stimulation, was downregulated by the addition of the $\mathrm{P} 7$ peptides.

qPCR was performed to validate the expression levels of CK8 identified by proteomic analysis. CK8 expression was upregulated by bFGF stimulation and decreased by the addition of the P7 peptides (Fig. 8). The result coincided with that obtained from proteomic analysis. 
Table I. Differentially expressed proteins identified by MALDITOF-TOF mass spectrometry.

\begin{tabular}{lcccc}
$\begin{array}{l}\text { Protein } \\
\text { name }\end{array}$ & Accession no. & Theor. Mw/pI & Score & CI \\
\hline CK8 & IPI00792642 & $24809.4 / 4.7$ & 366 & 100 \\
\hline
\end{tabular}

CK8, cytokeratin 8. MALDI-TOF-TOF, matrix-assisted laser desorption/ionization time-of-flight mass spectrometry. Theor. Mw/pI, theoretical molecular weight/isoelectric point.

\section{Discussion}

$\mathrm{CRC}$ is a type of lethal gastrointestinal malignancy. The main reason for its high mortality rate is the frequent relapse due to resistance to chemotherapeutic drugs. The development of novel targeted therapies will open up new opportunities to combat drug resistance. It was recently reported that bFGF plays an essential role in mediating chemoresistance, and thus may be served as a potential target for the development of new therapeutic strategies to combat the relapse of cancer $(25,26)$.

We previously obtained a novel bFGF antagonist peptide, P7, using phage display technology $(20,21)$. Our results indicated that P7 exerts strong inhibitory effects on bFGF-induced cell proliferation and angiogenesis by specifically inhibiting the binding of bFGF to its receptors. We speculated that the previously isolated $\mathrm{P} 7$ peptides targeting bFGF may also have potent inhibitory effects on bFGF-induced chemoresistance. Therefore, in this study, MTT assay was first carried out to investigate the effects of $\mathrm{P} 7$ peptides on bFGF-induced resistance to CPT-11. The results revealed that bFGF increased the survival rate of CPT-11-treated HT-29 cells; however, the survival rate decreased by the addition of $\mathrm{P} 7$ peptides, suggesting that $\mathrm{P} 7$ peptides reversed bFGF-induced resistance to CPT-11. Further analysis of the effects of P7 peptides on apoptosis, which is closely related to drug resistance in tumor cells, indicated that $\mathrm{P} 7$ peptides counteracted the anti-apoptotic effects of bFGF in CPT-11-treated cells.

The mechanisms responsible for the $\mathrm{P} 7$ peptides counteracting the anti-apoptotic effects of bFGF in CPT-11-treated cells were further explored by analyzing the effects of $\mathrm{P} 7$ peptides on the anti-apoptotic PI3K/Akt signaling pathway, bFGF internalization, and the expression of Bcl-2 family members involved in regulating the intrinsic pathway for the activation of apoptotic effectors. The role of Bcl-2 family members in regulating the response to chemotherapy has been extensively investigated. It has been demonstrated that the overexpression of the anti-apoptotic Bcl-2 family protein, Bcl-2, or the loss of the pro-apoptotic Bcl-2 family member, Bax, expression decreases sensitivity to chemotherapeutic agents (27-30), whereas the downregulation of Bcl-2 or the overexpression of Bax sensitizes cancer cells to chemotherapeutic agents (29). The ratio of Bax to Bcl-2 is usually applied to determine the susceptibility of cancer cells to chemotherapy-mediated apoptosis (31). Our results demonstrated that decrease in Akt activation, the suppression of bFGF internalization and the increase in the Bax to Bcl-2 ratio induced by $\mathrm{P} 7$ peptides contributed to the counteracting of the anti-apoptotic effects of bFGF, and the reversal of bFGFinduced resistance to CPT-11.

Proteomic analysis has been proven to be an efficient strategy for the identification of proteins involved in various pathologies. Therefore, we applied this approach to identify proteins associated with the effects of $\mathrm{P} 7$ peptides on bFGF-induced resistance of HT-29 cells to CPT-11. The differentially expressed protein spots identified by 2-DE were subjected to analysis by MALDITOF-TOF mass spectrometry, and were confidently identified by searching the data collected from MALDI-TOF-TOF against the IPI human database with the Mascot online search tool (Table I). The identified protein, CK8, whose expression level was further confirmed by qPCR, belongs to the keratin family of intermediate filament proteins, located on the cell surface of a variety of tumor cells, including colon cancer, breast cancer and liver cancer cells. Wang et al reported that the suppression of CK8 enchanced the sensitivity of the cells to cisplatin, while the overexpression of CK8 provided resistance to cisplatinmediated apoptosis in human nasopharyngeal carcinoma cells (32). Jaquemar et al demonstrated that CK8-deficient embryos were exquisitely sensitive to apoptosis (33). Previous studies have implicated CK8 in the resistance to tumor necrosis factor family receptor- and Fas-induced apoptosis $(34,35)$. Moreover, the activation of Akt increases CK8 expression at the post-transcriptional level, and the knockdown of Akt decreases CK8 protein levels (36). Our proteomic analysis revealed that P7 peptides reversed the upregulation of CK8 expression which was induced by bFGF. Combined with the results that P7 peptides decreased Akt activation induced by bFGF, it is reasonable to speculate that the downregulation of Akt activation by $\mathrm{P} 7$ peptides may result in the decreased expression of CK8, which would partly counteract the anti-apoptotic effects of bFGF, and would thus attenuate the resistance of HT-29 cells to CPT-11 induced by bFGF.

It has been previously demonstrated that $\mathrm{P} 7$ peptides inhibit tumor growth and progression through the suppression of cell proliferation and angiogenesis stimulated by $\operatorname{bFGF}(20,21,37,38)$. In this study, we demonstrated that $\mathrm{P} 7$ peptides have the potential to reverse bFGF-induced chemoresistance. It seems reasonable to speculate that $\mathrm{P} 7$ peptides combined with chemotherapeutic agents, such as CPT-11, may not only exert inhibitory effects on cell proliferation and angiogenesis, but may also enhance the antitumor efficacy of chemotherapeutic agents, resulting in greater therapeutic benefits in cancers characterized by bFGFinduced chemoresistance.

\section{Acknowledgements}

This study was supported by grants from the National Natural Science Foundation of China (81071800, 30973671), the Guangdong Provincial Science and Technology Program (2010B060900040), the Natural Science Foundation of Guangdong Province of China (9151064001000031), the Natural Science Foundation of Zhejiang Province of China (Y2110492), the Science and Technology Planning Project of Wenzhou (Y20090244), the Fundamental Research Funds for the Central Universities (X. Wu), Guangdong Provincial 'Thousand-Hundred-Ten Talent Project' (X. Wu) and the Key Laboratory of Functional Protein Research of Guangdong Higher Education Institutes, Jinan University. 


\section{References}

1. Kronborg O, Ugstad M, Fuglerud P, Johne B, Hardcastle J, Scholefield JH, Vellacott K, Moshakis V and Reynolds JR: Faecal calprotectin levels in a high risk population for colorectal neoplasia. Gut 46: 795-800, 2000.

2. Lum BL, Fisher GA, Brophy NA, Yahanda AM, Adler KM, Kaubisch S, Halsey J and Sikic BI: Clinical trials of modulation of multidrug resistance. Pharmacokinetic and pharmacodynamic considerations. Cancer 72 (Suppl 11): 3502-3514, 1993.

3. Barrand MA, Bagrij T and Neo SY: Multidrug resistance-associated protein, a protein distinct from P-glycoprotein involved in cytotoxic drug expulsion. Gen Pharmacol 28: 639-645, 1997.

4. Fidler IJ: Critical determinants of cancer metastasis: rationale for therapy. Cancer Chemother Pharmacol 43: S3-S10, 1999.

5. Broxterman HJ, Lankelma J and Pinedo HM: How to probe clinical tumour samples for P-glycoprotein and multidrug resistance-associated protein. Eur J Cancer 32A: 1024-1033, 1996.

6. Ferry DR, Traunecker H and Kerr DJ: Clinical trials of P-glycoprotein reversal in solid tumours. Eur J Cancer 32A: 1070-1081, 1996.

7. Hertzberg RP, Caranfa MJ and Hecht SM: On the mechanism of topoisomerase I inhibition by camptothecin: evidence for binding to an enzyme-DNA complex. Biochemistry 28: 4629-4638, 1989

8. Saltz LB, Cox JV, Blanke C, Rosen LS, Fehrenbacher L, Moore MJ, Maroun JA, Ackland SP, Locker PK, Pirotta N, Elfring GL and Miller LL: Irinotecan plus fluorouracil and leucovorin for metastatic colorectal cancer. Irinotecan Study Group. N Engl J Med 343: 905-914, 2000.

9. Ichiki M, Gohara R, Rikimaru T, Kitajima T, Fujiki R, Shimada A and Aizawa H: Combination chemotherapy with irinotecan and ifosfamide as second-line treatment of refractory or sensitive relapsed small cell lung cancer: a phase II study. Chemotherapy 49: 200-205, 2003.

10. Takeuchi S, Takamizawa H, Takeda Y, Ohkawa T, Tamaya T, Noda K, Sugawa T, Sekiba K, Yakushiji M and Taguchi T: An early phase II study of CPT-11 in gynecologic cancers. Research Group of CPT-11 in Gynecologic Cancers. Gan To Kagaku Ryoho 18: 579-584, 1991 (In Japanese).

11. Wall ME: Camptothecin and taxol: discovery to clinic. Med Res Rev 18: 299-314, 1998.

12. Fukuoka M, Niitani H, Suzuki A, Motomiya M, Hasegawa K, Nishiwaki Y, Kuriyama T, Ariyoshi Y, Negoro S and Masuda N: A phase II study of CPT-11, a new derivative of camptothecin, for previously untreated non-small-cell lung cancer. J Clin Oncol 10: 16-20, 1992.

13. Ohno R, Okada K, Masaoka T, Kuramoto A, Arima T, Yoshida Y, Ariyoshi H, Ichimaru M, Sakai Y and Oguro M: An early phase II study of CPT-11: a new derivative of camptothecin, for the treatment of leukemia and lymphoma. J Clin Oncol 8: 1907-1912, 1990

14. Shimada Y, Yoshino M, Wakui A, Nakao I, Futatsuki K, Sakata Y, Kambe M, Taguchi T and Ogawa N: Phase II study of CPT-11, a new camptothecin derivative, in metastatic colorectal cancer. CPT-11 Gastrointestinal Cancer Study Group. J Clin Oncol 11: 909-913, 1993.

15. Shirao K, Shimada Y, Kondo H, Saito D, Yamao T, Ono H, Yokoyama T, Fukuda H, Oka M, Watanabe Y, Ohtsu A, Boku N, Fujii T, Oda Y, Muro K and Yoshida S: Phase I-II study of irinotecan hydrochloride combined with cisplatin in patients with advanced gastric cancer. J Clin Oncol 15: 921-927, 1997.

16. Takeuchi S, Dobashi K, Fujimoto S, Tanaka K, Suzuki M, Terashima Y,Hasumi K, Akiya K, Negishi Y and Tamaya T: A late phase II study of CPT-11 on uterine cervical cancer and ovarian cancer. Research Groups of CPT-11 in Gynecologic Cancers. Gan To Kagaku Ryoho 18: 1681-1689, 1991 (In Japanese).

17. Rusnati $M$ and Presta $M$ : Fibroblast growth factors/fibroblast growth factor receptors as targets for the development of antiangiogenesis strategies. Curr Pharm Des 13: 2025-2044, 2007.

18. Cronauer MV, Schulz WA, Seifert HH, Ackermann R and Burchardt M: Fibroblast growth factors and their receptors in urological cancers: basic research and clinical implications. Eur Urol 43: 309-319, 2003.
19. Gross JL, Herblin WF, Dusak BA, Czerniak P, Diamond MD, Sun T, Eidsvoog K, Dexter DL and Yayon A: Effects of modulation of basic fibroblast growth factor on tumor growth in vivo. J Natl Cancer Inst 85: 121-131, 1993.

20. Wu X, Yan Q, Huang Y, Huang H, Su Z, Xiao J, Zeng Y, Wang Y, Nie C, Yang Y and Li X: Isolation of a novel basic FGF-binding peptide with potent antiangiogenetic activity. J Cell Mol Med 14: 351-356, 2010.

21. Wang C, Lin S, Nie Y, Jia X, Wang J, Xiao J, Wu J, Li X and Wu X: Mechanism of antitumor effect of a novel bFGF binding peptide on human colon cancer cells. Cancer Sci 101: 1212-1218, 2010.

22. Bonnet H, Filhol O, Truchet I, Brethenou P, Cochet C, Amalric F and Bouche G: Fibroblast growth factor- 2 binds to the regulatory beta subunit of CK2 and directly stimulates CK2 activity toward nucleolin. J Biol Chem 271: 24781-24787, 1996.

23. Bradford MM: A rapid and sensitive method for the quantitation of microgram quantities of protein utilizing the principle of protein-dye binding. Anal Biochem 72: 248-254, 1976

24. Sorensen V, Nilsen T and Wiedlocha A: Functional diversity of FGF-2 isoforms by intracellular sorting. Bioessays 28: 504-514, 2006.

25. Gan Y, Wientjes MG and Au JL: Expression of basic fibroblast growth factor correlates with resistance to paclitaxel in human patient tumors. Pharm Res 23: 1324-1331, 2006.

26. Walsh CT, Wei Y, Wientjes MG and Au JL: Quantitative image analysis of intra-tumoral bFGF level as a molecular marker of paclitaxel resistance. J Transl Med 6: 4, 2008

27. Wang Q, Maloof P, Wang H, Fenig E, Stein D, Nichols G, Denny TN, Yahalom J and Wieder R: Basic fibroblast growth factor downregulates Bcl-2 and promotes apoptosis in MCF-7 human breast cancer cells. Exp Cell Res 238: 177-187, 1998.

28. Burchill SA and Westwood G: Mechanism of basic fibroblast growth factor-induced cell death. Apoptosis 7: 5-12, 2002.

29. Coleman AB: Positive and negative regulation of cellular sensitivity to anti-cancer drugs by FGF-2. Drug Resist Updat 6: 85-94, 2003.

30. Maloof P, Wang Q, Wang H, Stein D, Denny TN, Yahalom J, Fenig E and Wieder R: Overexpression of basic fibroblast growth factor (FGF-2) downregulates Bcl-2 and promotes apoptosis in MCF-7 human breast cancer cells. Breast Cancer Res Treat 56: 153-167, 1999.

31. Raisova M, Hossini AM, Eberle J, Riebeling C, Wieder T, Sturm I, Daniel PT, Orfanos CE and Geilen CC: The Bax/Bcl-2 ratio determines the susceptibility of human melanoma cells to CD95/Fas-mediated apoptosis. J Invest Dermatol 117: 333-340, 2001.

32. Wang Y, He QY, Tsao SW, Cheung YH, Wong A and Chiu JF: Cytokeratin 8 silencing in human nasopharyngeal carcinoma cells leads to cisplatin sensitization. Cancer Lett 265: 188-196, 2008.

33. Jaquemar D, Kupriyanov S, Wankell M, Avis J, Benirschke K, Baribault $\mathrm{H}$ and Oshima RG: Keratin 8 protection of placental barrier function. J Cell Biol 161: 749-756, 2003.

34. Caulin C, Ware CF, Magin TM and Oshima RG: Keratindependent, epithelial resistance to tumor necrosis factor-induced apoptosis. J Cell Biol 149: 17-22, 2000.

35. Gilbert S, Loranger A, Daigle N and Marceau N: Simple epithelium keratins 8 and 18 provide resistance to Fas-mediated apoptosis. The protection occurs through a receptor-targeting modulation. J Cell Biol 154: 763-773, 2001.

36. Fortier AM, Van Themsche C, Asselin E and Cadrin M: Akt isoforms regulate intermediate filament protein levels in epithelial carcinoma cells. FEBS Lett 584: 984-988, 2010.

37. Wang C, Yu Y, Li Q, et al: P7 peptides suppress the proliferation of K562 cells induced by basic fibroblast growth factor. Tumour Biol 33: 1085-1093, 2012

38. Yu Y, Gao S, Li Q, et al: The FGF2-binding peptide P7 inhibits melanoma growth in vitro and in vivo. J Cancer Res Clin Oncol 138: 1321-1328, 2012. 